\title{
ARTESANATO EM CASCA DE COCO: UMA FONTE DE RENDA ECOLOGICAMENTE CORRETA
}

\author{
Ana Paula Foletto Pedroso, Esp. (FIJ); \\ Selma de Aguiar Rocha, M.Sc. (UNIPLI)
}

\section{INTRODUÇÃO}

O coqueiro e seus frutos, presentes em dezenas de países, têm grande importância na vida e na economia de várias populações. Com criatividade, respeito e responsabilidade ambiental, pode atuar como um aliado na preservação da cultura brasileira e sua capacidade de transformação social em diversas regiões do país.

A possibilidade de utilização da casca do coco e a fibra do coco, resíduos da indústria de água de coco, coco ralado, e demais derivados, substituindo outros materiais na fabricação de biojóias, acessórios, adornos, e artefatos decorativos e funcionais, além de minimizar os impactos ambientais, não ser poluente e não ser proveniente de desmatamento, confere ao objeto um aspecto diferenciado, possibilitando unir a funcionalidade aos aspectos decorativos que evidenciam o produto pela exposição da matéria-prima.

Uma das formas com que se verificou a viabilidade do projeto foi a realização de pesquisa de aceitação de produtos em casca e fibra de coco, por meio da aplicação de questionários, aleatoriamente, nas ruas da cidade de Itajaí-SC, a fim de identificar o potencial de consumo, tipos de artefatos mais rentáveis para os artesãos desenvolverem e possíveis locais de venda.

\section{ANÁLISE DE ACEITAÇÃO DO PRODUTO}

Através da análise dos questionários aplicados, foi possível chegar a alguns conceitos principais listados abaixo:

- Preço, beleza e facilidade de uso foram os três itens mais citados pelos entrevistados, portanto devem ser considerados no desenvolvimento do produto.

- Como boa parte dos entrevistados (32\%), prefeririam encontrar produtos em casca e fibra de coco à venda em feiras de artesanato, ou em camelôs, se define um local popular que atingiria facilmente esse público-alvo. Vinte por cento dos entrevistados citou lojas como um ponto de venda ideal.

- Seria atrativo, em questão de aceitação no mercado, concentrar-se na produção de biojóias, e artigos decorativos em casca e fibra de côco, pois foram os itens de maior interesse de aquisição por parte do público

particpante da pesquisa, o que identifica esses objetos como os tipos de artefatos mais rentáveis.

- O fato de $70 \%$ dos entrevistados considerarem os produtos artesanais interessantes, sinaliza uma abertura ao desenvolvimento inicialmente artesanal, de produtos em casca e fibra de coco por parte das comunidades, como também a possibilidade de difusão de técnicas de beneficiamento e produção em maior escala com esta matéria-prima até mesmo pelo sistema de cooperativas.

Portanto, casca e a fibra de coco, já inseridas na crescente exigência em nível global de produtos ecologicamente corretos, e de interesse do público consumidor, proporcionam além dos diferenciais que destacam o produto daqueles que não possuem as mesmas características, uma forma de contribuição pessoal do consumidor para a preservação do planeta.

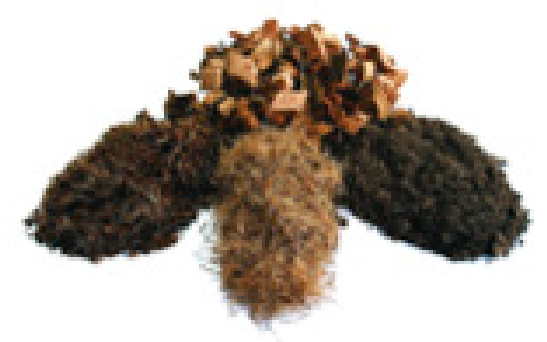

Fonte: http://www.cocoverderj.com.br

Nesse sentido, novos produtos e serviços coerentes com uma perspectiva de sustentabilidade a médio e longo prazo, devem ser, ao mesmo tempo, economicamente alcançáveis e socialmente apreciáveis hoje, principalmente no caso do Brasil, com as potencialidades de seus recursos renováveis e a dimensão de seus problemas sociais.

\section{REFERÊNCIAS}

LAVRINI, Oscar; Moura, Wilson. Fibra de coco - história, uso e tendências. POEMAtropic. POEMA, v.3, n5. Belém, 2000.

OTTMAN, Jacquelyn A. Marketing verde. Tradução Marina Nascimento Paro. São Paulo: Makron, c1994. 
MANZINI, Ezio. \& VEZZOLI Carlo. O Desenvolvimento de Produtos Sustentáveis. Os requisitos ambientais dos Produtos Industriais. Edusp, 2002

MAY, P.; LUSTOSA, M. C.; VINHA, da. Economia do Meio Ambiente: Teoria e Prática. Rio de Janeiro: Elsevier, 2003

SOUSA, Alberto. Educação pela arte e arte na educação. Lisboa. Instituto Piaget. $1^{\circ}$ volume. 2003.

http://www.cocoverderj.com.br 